University of Louisville

ThinkIR: The University of Louisville's Institutional Repository

Faculty Scholarship

2020

\title{
A Foot in Both Worlds: Current Roles and Challenges of Academic Online Learning Librarians
}

Amber Willenborg

University of Louisville, amber.willenborg@louisville.edu

Tessa Withorn

California State University, Dominguez Hills, twhithorn@csudh.edu

Follow this and additional works at: https://ir.library.louisville.edu/faculty

Part of the Library and Information Science Commons

\section{Original Publication Information}

Withorn, T., \& Willenborg, A. (2020). A Foot in Both Worlds: Current Roles and Challenges of Academic

Online Learning Librarians. Journal of Library \& Information Services in Distance Learning 14(2), 110-126.

ThinkIR Citation

Willenborg, Amber and Withorn, Tessa, "A Foot in Both Worlds: Current Roles and Challenges of Academic Online Learning Librarians" (2020). Faculty Scholarship. 532.

https://ir.library.louisville.edu/faculty/532

This Article is brought to you for free and open access by ThinkIR: The University of Louisville's Institutional Repository. It has been accepted for inclusion in Faculty Scholarship by an authorized administrator of ThinkIR: The University of Louisville's Institutional Repository. For more information, please contact thinkir@louisville.edu. 


\section{A foot in both worlds: Current roles and challenges of academic online learning librarians}

T. Withorn ${ }^{\mathrm{a} *}$ and A. Willenborg ${ }^{\mathrm{b}}$

${ }^{a}$ University Library, California State University Dominguez Hills, Carson, USA;

${ }^{b}$ Ekstrom Library, University of Louisville, Louisville, USA

twithorn@csudh.edu*corresponding author

\section{Disclosure Statement}

No potential conflict of interest was reported by the authors.

This article has been accepted for publication in Journal of Library \& Information Services in Distance Learning, published by Taylor \& Francis, available at https://doi.org/10.1080/1533290X.2020.1828220 


\title{
A foot in both worlds: Current roles and challenges of academic online learning librarians
}

\author{
This qualitative study explores how online learning is defined at academic \\ libraries in the U.S. and examines the current roles and challenges of online \\ learning librarians. Findings from in-depth interviews reveal varied approaches to \\ online learning in terms of audience and instructional strategies, and that online \\ learning librarians face challenges related to their roles. Based on these findings, \\ the functional role of the online learning librarian should be clearly delineated \\ and leveraged to support sustainable online learning initiatives at the institution. \\ The authors make recommendations for librarians and library administrators to \\ support this evolving area of librarianship.
}

Keywords: academic libraries, academic librarianship, online learning, distance library services

\section{Introduction and Literature Review}

Distance and online learning librarianship have a long and divergent history in the profession. Academic libraries have been providing "extended campus" library services for over half a century, and the American Library Association has provided professional resources for distance learning librarians through the currently-named Distance Learning Section (DLS) of the Association of College and Research Libraries (ACRL) since 1991 (Frederiksen, 2004). However, the ACRL "Standards for Distance Learning Library Services," which ensure equitable access to library services and resources for "individuals at a distance," clearly distinguish distance learning from online learning in terms of remote access and geographic distance from a main campus rather than the more dynamic online learning environments students, instructors, and librarians increasingly inhabit (Association of College and Research Libraries [ACRL], 2016). As more public and private nonprofit colleges and universities offer online courses and degree programs, nearly a third of students take at least one online course and more than half of college students enrolled in fully online programs choose to attend affordable 
institutions relatively close to where they live (Aslanian et al., 2019; Ginder et al., 2019). These recent trends in online learning highlight a shift in modality but not necessarily geographic distance, which complicates definitions of online and distance learners.

At the same time, academic libraries are reframing distance learning services as reference and instruction positions that specialize in online resources, tools, and support for all library users. Jaguszewski and Williams (2013) note this trend away from subject-specialists toward functional specialists with new areas of expertise such as copyright, data management, user experience, instructional design, and online or elearning. While there is clearly a need in academic libraries for functional specialists in online learning, it remains unclear how online learning is defined and how the role of an online learning librarian fits into existing models for reference, outreach, and information literacy instruction. In a retrospective analysis of job announcements for distance education librarians, Tang (2013) traces the shift in job titles away from "extended," "distance," and "off-campus" toward "e-learning" and "online learning" over several decades. Alongside a decline in these positions, Tang (2013) notes a blurring of the distinction between "on-campus and off-campus" library users, and concern for overlapping job responsibilities with other reference and instruction librarians. Capturing the full breath of online librarianship, Pitts et al. (2019) outline best practices for reference, instruction, embedded librarianship, marketing, and outreach in Library Services for Online Patrons: A Manual for Facilitating Access, Learning, and Engagement; however, they are also careful to delineate online learning from distance learning. Likewise, they define the online audience as individuals "interacting with the library though the Internet" versus individuals "who are unable to, or prefer not to, visit our physical library locations" (Pitts et al., 2019, p. xii). The vast 
majority of academic libraries in the United States reach both of these audiences by providing online research assistance and online instructional materials in a variety of modes, including but not limited to email, phone/SMS, chat, video conferencing, instructional videos, research guides, interactive tutorials, and modules (Yang \& Dalal, 2015; Saunders, 2018). These job responsibilities often fall to reference and instruction librarians who may or may not specialize in online learning. While librarians are wellequipped to provide many online library services, Saunders's (2018) content analysis of publicly available learning objects highlights a lack of staffing or functional expertise to create online content in particular, noting that many libraries link to and borrow from vendors and other institutions (p. 277).

Although the "Standards" recognize the changing nature of distance learning in higher education, online learning librarians are left with few professional resources that clearly define their audience, role, and varied job responsibilities (ACRL, 2016). Related guiding documents including ACRL's “Guidelines for Instruction Programs" and "Roles and Strengths of Teaching Librarians" have few references to online learning aside from modes of instruction and instructional design for online content (ACRL, 2011; ACRL, 2017). Previous studies that identify characteristics, responsibilities, skills, and challenges of distance librarians do not fully reflect the shifting roles of online learning librarians who are responsible for supporting a mixed audience of library users in a variety of online learning environments, including the library's website and the learning management system (LMS), and not just those library users who are separated at a distance from the physical library (Brandt et al., 2006; Cassner \& Adams, 2004; Gandhi, 2003). Tang (2013) calls for future research to "determine how duties and responsibilities are developed for whatever new positions replace what used to be called 'distance education librarians"' (p. 504). The present 
study contributes to gaps in the literature by exploring the current roles and challenges of online learning librarians using extensive semi-structured interviews to gain insights into the unique experiences and perspectives of librarians with this functional expertise and how their work differs from their reference and instruction colleagues. For the purposes of this study, the authors considered online learning broadly in terms of support for online students, instructors, instructional designers, and academic technologists in using library resources and delivering information literacy instruction, either synchronously or asynchronously. The exploratory research questions guiding this study are as follows:

- How do academic libraries define online learning?

- What are the current roles of academic online learning librarians?

- What challenges do academic online learning librarians face at their institutions?

\section{Methods}

The purpose of this qualitative interview study is to explore definitions of online learning in academic libraries, examine current roles and challenges of academic online learning librarians, and make recommendations that support librarians and academic libraries in keeping pace with shifting modalities for learning in higher education. Since the authors were interested in how participants described their role and approaches, interview responses were the primary object of study and discourse analysis was used to interpret and classify responses (Frohmann, 1994). Through discourse analysis, researchers reveal similarities and differences based on the social context of a discipline in a way that "systematizes different ways of talking in order to make visible the perspectives and starting points on the basis of which knowledge and meanings are produced in a particular historical moment" (Talja, 1999, p. 460). Interview responses in this study capture the historical moment of the current roles and challenges of online 
learning librarians, and the authors contextualize interview data within the literature of online learning in academic libraries and higher education.

Data for this study was collected as part of a larger investigation into the roles, skills, and challenges of academic online learning librarians, which was approved by the authors' respective Institutional Review Boards in December 2019. A sample of online learning librarians and equivalent positions was collected using a publicly available list of member institutions of LOEX, which largely represents academic libraries interested in information literacy instruction from various regions of the United States and Canada. Thirty-five participants were identified based on publicly available information on library websites as 1) currently employed by an academic library in the United States and 2) holding a job title including Online Learning Librarian, eLearning Librarian, or an equivalent title. The authors directly recruited thirty-five qualifying participants by email invitation, and seventeen agreed to be interviewed. The authors determined a response rate of $47.22 \%$ to be a representative sample size.

Of the seventeen total participants, nine self-identified as female, seven selfidentified as male, and one self-identified as nonbinary and genderqueer. Fifteen participants identified as White or Caucasian, one participant identified as Hispanic and Mexican, and one participant identified as Chinese-American. Participants ranged in age from 29 to $50(M=37 ; S D=6.85)$, and their length of employment as a professional librarian ranged from 3 to 20 years $(M=9.1 ; S D=5.12)$. Most participants held a Master of Library and Information Science or equivalent degree $(n=16)$, and one participant held a related advanced degree. Represented institutions by Carnegie Classification included Doctoral $(\mathrm{n}=15)$, Baccalaureate $(\mathrm{n}=1)$, and Two-Year Associate's ( $\mathrm{n}=1)$, ranged in approximate institutional size from 2,500 to 100,000 fulltime equivalent enrollment, and were located across the continental United States, 
including the Northeast $(n=5)$, Midwest $(n=3)$, South $(n=4)$, and West $(n=5)$. Although demographic variables of librarians did not emerge as a theme in this analysis, the authors determined the sample of librarians and academic institutions to be sufficiently varied.

The authors conducted semi-structured interviews (see Appendix) with each participant in early 2020 over the phone and web conferencing, each lasting approximately one hour. Participants were prompted to answer questions about their professional background, current institution and roles, perceived skills and challenges, and basic demographic variables. When defining online learning, participants were asked to elaborate in terms of their department, library, or institution as a whole. Participants described various approaches to online learning, including embedded librarianship in the LMS, developing online instructional materials, and providing online research assistance; however, specific pedagogies, technologies, and perceived skills were not explored in this study. In some cases, the authors asked follow-up questions to a participant's initial response in order to gain a better understanding of their institutional context.

Interviews were recorded with consent, de-identified, and transcribed for analysis. After an initial review of the transcripts, the authors collaboratively developed discourse categories, and identified relevant interview quotes that align with the research questions: 1) definitions of online learning; 2) online learning librarian roles; and 3) challenges faced by online learning librarians at their institution. When referenced or quoted directly, participants are identified with pseudonyms. 


\section{Results}

\section{Defining Online Learning in Academic Libraries: Three Approaches}

The first research question explored definitions of online learning in academic libraries. When asked how online learning is defined in their library, respondents most often described their library's approach to online learning in terms of the audience for online learning initiatives and strategies for reaching an online learning audience. Three primary approaches to online learning emerged in these definitions: 1) universal, described as supporting anyone using the library online; 2) integrated, described as supporting students and instructors within the institution's learning management system (LMS); and 3) programmatic, described as supporting students and instructors involved in fully online programs. While some respondents mentioned several approaches taken by their library, each participant was categorized with a single definition for their primary approach to online learning. Those targeting similar audiences often shared comparable outreach and instructional strategies.

\section{Integrated}

The largest number of respondents primarily described their approach to online learning and their audience as integrated in the LMS. These eight respondents provide support to any course with an online component within the LMS, whether the course is in-person, online, or hybrid. Carole has noticed a recent shift to this definition at her institution: "Online learning I think has migrated to what happens in our course management system." The most common strategy for reaching this audience is some form of embedded librarianship, described as creating coursespecific asynchronous online instructional materials such as modules, tutorials, research guides, and videos for use in the LMS and individualized research assistance. Some librarians also described working closely with instructors, 
instructional designers, and academic technologists to further integrate the library into online learning environments.

\section{Programmatic}

Academic libraries with a programmatic approach to online learning target students and instructors involved in fully online or distance degree programs. Seven librarians described their library as taking a programmatic approach. Gladys's position was created in response to the growth of online programs at her institution: "In our library it's defined as basically the point person for working with online students $[\ldots]$ [this position was] requested after our online programs got off the ground." Librarians targeting online programs did not share a common strategy for supporting online students and instructors. Respondents in this group had the broadest range of strategies including providing online research assistance, creating general and course-specific online instructional materials, providing embedded support in the LMS, and working closely with instructors, instructional designers, and academic technologists.

\section{Universal}

Only two respondents described their library's primary approach to online learning as universal, targeting the broadest audience of anyone interacting with the library online. Lauren stated that "I think we're kind of working on a definition [of online learning], but in the time that I've been here it's been not necessarily working with our online programs but more working with like LibGuides and our online chat services, but not just for online students if that makes sense." The primary strategies for reaching this broad audience of online learners include creating general online instructional materials like research guides, videos, and modules in the LMS, as well as working directly with online instructors to integrate these resources. 


\section{Current Roles of Online Learning Librarians}

The second research question examined the current roles of academic online learning librarians. Seven common roles were identified: 1) content builder, 2) instructional designer, 3) liaison, 4) coordinator, 5) trainer, 6) advocate, and 7) slasher. All seventeen respondents perform at least two of these roles with some involved in as many as six. Patterns emerged in the roles of librarians whose libraries take similar approaches to online learning.

\section{Content Builder}

Content builders spend considerable time creating modules, interactive tutorials, research guides, videos, and other online instructional materials using educational and design technology. Joshua described his role as a content builder: "I create a lot of digital learning objects. So I create videos, I create learning modules and those sorts of things." Eleven librarians were categorized as content builders, most of whom work at libraries taking a universal or integrated approach to online learning where the primary instructional strategy involves creating general and course-specific online instructional materials.

\section{Instructional Designer}

Instructional designers focus on learning theory when designing and developing online learning experiences. Several participants, including Anne, differentiated their instructional design work from that of content building: "I don't do as much of the production work, more at the theoretical design level.” Nine librarians were categorized as instructional designers and are divided between libraries taking integrated and programmatic approaches to online learning, which may be associated with the fact that several of these librarians have obtained or are currently working on advanced degrees 
in instructional design, instructional technology, or a related field and are using this knowledge in their work.

\section{Liaison}

Liaisons directly assist and provide outreach to online learning stakeholders. Dillon explains this role as: "It's very much like my other colleagues who are subject librarians. I kind of think of it using the same subject librarian model that I'm used to working with and that I think a lot of schools use. I see myself as the liaison to the online college." Eleven librarians were categorized as liaisons, and this role is least common at libraries taking an integrated approach to online learning. While librarians with a programmatic approach have a well-defined constituency for their liaison workfully online programs or online learning departments on campus - those in libraries taking an integrated approach focus on a broader audience of in-person, hybrid, and online courses within the LMS that make targeted liaison work more difficult.

\section{Coordinator}

Coordinators build and manage relationships among online learning stakeholders and often lead a team for online learning. Sylvia manages "a team of three classified staff and a graduate student" and her job is to "basically come up with projects that need to be done based on something I've identified or something that's been directed to me." Other coordinators described managing relationships between subject librarians and instructors and building relationships with online learning units on campus. Seven of the nine librarians with coordinator responsibilities are at a library taking an integrated approach to online learning, where supporting the broad population of online learners within the LMS often requires involvement from other librarians. 


\section{Trainer}

Trainers prepare their librarian colleagues and others within the institution to implement online learning tools and techniques. There is noticeable overlap among librarians in the coordinator and trainer roles, suggesting coordination also involves time spent training others. Marsha has "provided some one-on-one training with my [library] colleagues on accessibility and creating accessible videos and tutorials." Trainers also described working with others outside the library like instructors and instructional designers. Eight librarians were categorized as trainers and are most common at libraries taking an integrated approach to online learning, where librarians are highly involved in the LMS and show value by sharing their expertise about online resources, library-licensed materials, and open educational resources with other librarians, instructors, and instructional designers.

\section{Advocate}

Advocates consider themselves a voice for online students on issues related to equity, access, and privacy. Dillon believes that "it's part of my job to advocate for that population in various ways and keep their needs in mind and try to give them, insofar as it's possible, give them the same quality experience of library instruction or library services that a student who is physically present on campus would have." The eight librarians categorized as advocates are dispersed among libraries taking universal, integrated, and programmatic approaches to online learning, demonstrating that advocacy is an important component of online learning librarianship across academic libraries. 


\section{Slasher}

The six roles outlined above illustrate the wide range of duties involved in online learning work, from creating online instructional content and providing outreach to online constituents to coordinating relationships among online learning stakeholders and advocating on behalf of online students. However, the most frequent theme among online learning librarians when asked to describe their role was that online learning is only a part of their job, and often not the part that takes up the most time. Fifteen of the seventeen respondents were categorized as slashers who have job responsibilities outside of online learning including face-to-face instruction, shifts on a reference desk, and outreach to assigned academic departments. Joshua described his job duties as “probably about fifty-fifty" between online content creation and "subject librarian duties and teaching and instruction." For some respondents, including Howard, online learning was described as an add-on: "I obviously have responsibilities here in the library, reference, staffing the reference desk, teaching library instruction classes, a lot of the same responsibility most of us instruction librarians have. And on top of that I'm also pretty heavily involved in the online learning aspects of that."

For slashers, the duties they perform outside of online learning are often integral to their library's departmental structure or lack thereof. The majority of respondents either work in departments dedicated to reference and instruction $(n=8)$ or in libraries with no departmental structure $(n=8)$, with only one respondent working in a technical services department $(n=1)$. Tim's position is housed in the library's reference department and was created as a way to "kill two birds with one stone... with the reference and instruction and all the online learning." Lauren works in a library with fewer staff, but the creation of her position was similarly motivated: "From what I understand, the school was considering not filling a third position, so they had to create 
an online learning librarian position to kind of sell the fact that they needed another librarian." While these librarians' institutions have recognized the benefit of hiring an online learning librarian, they have not delineated the functional role of online learning librarians from the existing duties of their colleagues.

\section{Challenges in Online Learning Librarianship}

The third and final research question explored current challenges of online learning librarians. Respondents were asked to describe challenges they face in their online learning work, and four themes arose in librarians' responses: 1) workload, 2) silos, 3) access, and 4) resources. Each of these challenges act as a barrier to librarians in fulfilling their online learning roles and in moving online learning initiatives forward at their institution.

\section{Workload}

The most common challenge expressed by online learning librarians is strongly associated with the slasher role performed by many respondents. Twelve of the seventeen respondents discussed being constrained by an unrealistic workload, making it difficult to prioritize online learning over other reference and instruction work. Marc notes that "creating online learning objects becomes like when I have time." Similarly, Sylvia tries to prioritize online learning but feels pressure from her colleagues to focus on other responsibilities: "I feel the push and pull of, well you need to sit and do on-call reference at the desk and I'm like well nobody's coming and I could really use these hours to work with my team to build this learning module or to experiment with new things. So being expected to have a foot in both worlds is good but it's also a challenge." Tasked with the other duties in addition to online learning roles like creating content, training, and coordinating, online learning librarians can feel like they are 
trying to balance two jobs at once. This challenge illustrates academic libraries' struggle to fit the functional role of online learning librarians into existing models of reference and instruction.

Silos

Another challenge faced by many respondents is the presence of silos among online learning stakeholders at their institution. Eleven librarians described being hindered by not knowing who to contact or partner with and thus being left out of broader online learning conversations at their institution. Howard discussed the difficulty he faces connecting with separate online learning units: "it can be kind of frustrating to sort of identify the correct people to approach." Similarly, Joe describes this challenge as: "a big part of working with [the online campus] is making sure that the right person is looped into the conversation, that either being the instructor or instructional designer, and sometimes finding out who the right person to talk to is can be a challenge." Librarians who have found appropriate partners often still feel the impact of institutional silos; Erik works with academic technologists and instructional designers but described himself as being "something of like a fifth wheel" in those conversations. These institutional silos present a significant obstacle for online learning librarians, particularly in their roles as coordinators and advocates. Without the ability to identify partnerships and have a seat at the table in online learning conversations, online learning librarians have difficulty building successful relationships with online learning stakeholders and acting as a voice for online students and the library.

Access

Online learning librarians also face barriers accessing students and instructors in online learning environments. For the ten librarians facing this challenge, several described 
that the issue of access stems from needing instructor buy-in to reach online students. Marsha elaborates: "it's very hard to get instructors on board with that because they kind of see librarians, the embedded librarian as an interloper versus somebody that can help.” Jamie also sees the library being under-utilized by instructors in online courses: "sometimes faculty who teach online, even if when they teach in person they are library users or they're interested in having a librarian in their classroom, when they move to online $[. .$.$] they're kind of like I don't understand how you fit now." Without access to$ the online students and instructors they are charged with supporting, online learning librarians face a considerable barrier to liaison outreach and providing online research assistance and information literacy instruction.

\section{Resources}

A final challenge, and one that is not unique to online learning librarians, is a lack of resources like staffing and funding to adequately perform their roles. Nine respondents discussed a lack of resources, including the need for more staff to support online learning. Anne stated that her biggest challenge is "really the fact that I need more help" from her colleagues with online learning initiatives, and Marc described difficulty supporting his institution's "rapidly growing" online programs. Another resource online learning librarians lack is appropriate funding for technology. Sylvia’s library does not prioritize online learning in the budget: "Our administration is very traditional and focused on collection development $[\ldots]$ so that's where the bulk of our budget goes, so that makes it hard to make requests for the new software. It's like why isn't there a process for this or why do I have to beg for this or why are you telling me to go find something free, like there's a reason why I haven't." A lack of funding for software and technology has the potential to negatively impact the quality of modules, tutorials, and videos created by content builders, while the lack of staffing and support could diminish 
an online learning librarian's ability to perform each of their varied roles proficiently if overwhelmed by being the sole librarian responsible for supporting online learning for the entire institution.

\section{Discussion \& Recommendations}

The purpose of this study was to examine how academic libraries define online learning and to explore the current roles and challenges of online learning librarians. In doing so, this research highlights a continued shift in academic libraries toward services targeting a broader audience of online library users and describes the functional expertise of online learning librarians. Fewer than half of respondents categorized their library's approach to online learning as programmatic, a definition that aligns with an understanding of distance learning that supports individuals who are geographically separated from the library (ACRL, 2016). The majority of respondents provided an integrated or universal definition of online learning in line with Pitts et al. (2019), supporting individuals interacting with the library online, whether that be through the library's website or their institution's LMS.

Furthermore, this study contributes to the literature on the changing nature of distance and online learning in academic libraries while also answering Tang's (2013) call for research on the responsibilities of online and e-learning librarians. As opposed to job descriptions and announcements, in-depth interviews provide insight into the current and expanding roles of online learning librarians as they support a growing audience of online library users. Adding to Tang's (2013) concern for the overlapping job responsibilities of online learning librarians and their reference and instruction colleagues, the present findings reveal that online learning librarians ubiquitously take part in other duties, such as face-to-face reference and instruction and subject-liaison work, in addition to distinct online learning roles like content building, instructional 
design, coordination, and training. The pervasiveness of the slasher role among respondents makes clear that while academic libraries may have defined their approach to online learning and benefit from hiring an online learning librarian with functional expertise, they have yet to clearly delineate the role of online learning librarians within the existing structure of the library and differentiate their work from their colleagues.

Online learning librarians in this study revealed several challenges to fulfilling their roles, the most prevalent of which was the workload associated with performing online learning duties in addition to other responsibilities that often take precedence. As online course offerings at colleges and universities continue to grow and academic library services evolve to meet the changing needs of library users, academic libraries are called to examine how online learning librarians and other functional specialists fit into existing models for reference, outreach, and information literacy instruction. By identifying challenges faced by online learning librarians in fulfilling these varied roles, the authors are able to provide librarians and library administrators with recommendations to better support this distinct area of librarianship.

\section{Recommendations for Librarians and Academic Libraries}

Based on the roles and challenges identified in this study, the authors recommend that academic libraries cultivate organizational structures that enable online learning librarians to focus on their functional role and lead online learning initiatives with others. Interestingly, collaboration among library colleagues for online learning did not emerge as a significant theme in this study aside from coordination and training, and many participants reported that other librarians are separately responsible for aspects of online learning such as online research assistance, creating online research guides, and supporting online courses with information literacy instruction. Challenges related to 
workload and resources highlight the need for more clearly defined roles for online learning librarians and their reference and instruction colleagues in order to fully utilize their functional expertise. As noted by Jagueszeweki and Williams (2013), a hybrid model pairing the expertise of subject liaisons and functional specialists through a teambased approach would allow online learning librarians to work more effectively with their colleagues and online learning stakeholders on campus. Academic libraries with and without an online learning librarian can look to University of Nevada Las Vegas' integrated collection development structure (Day \& Novak, 2019) and Wissinger et al. (2018) as models for creating online learning teams that leverage functional expertise to integrate the library into the institution's teaching and research mission. Moving toward a hybrid or team-based model for online learning initiatives would also mitigate challenges of silos, access, and resources by allowing for more time and resources needed for online learning librarians to create and maintain relationships with online students and instructors and build partnerships with other online learning stakeholders on campus. By alleviating the strain of having a foot in both worlds of online learning and other duties as assigned, online learning librarians can function more effectively and lead sustainable online learning initiatives in their dedicated role.

\section{Recommendations for Library Administrators}

Academic library administrators also play a role in enabling online learning librarians to focus on their functional role in their organizational structures, and can address some institutional barriers. Additional recommendations for administrators were gleaned from participants' responses to how their library can better support their online learning work. Administrators should use their position and institutional connections to facilitate relationships between online learning librarians and the institution's center for teaching and learning, online learning, and other equivalent partners to help the online learning 
librarian overcome institutional silos. Additionally, administrators should recognize that supporting the institution's growing number of online programs and learners requires software and other technology needs and consider this when budgeting. For academic libraries looking to hire an online learning librarian, the roles and challenges identified in this study can inform the development of a job description in consultation with librarians.

\section{Limitations and Future Research}

This study provides an in-depth look at the experiences of online learning librarians in academic libraries, focusing on libraries' shifting definitions of online learning and the roles performed and challenges faced by online learning librarians. The authors acknowledge some limitations to the present study. Both authors are currently online learning librarians at academic libraries with their own definitions of online learning, roles, and challenges that may have unknowingly influenced their analysis of results despite the intention to remain objective. Additionally, the results of this study represent perspectives from librarians in dedicated online learning roles based on their job title and do not capture the experiences of reference and instruction librarians with different titles who are also doing this work in academic libraries. Finally, fifteen of the seventeen librarians interviewed are employees of doctoral-granting institutions; the roles and challenges of online learning librarians at other institution types might look very different and could be explored in future research. Future research could also explore the roles and challenges of online learning librarians whose organizational structures allow them to focus on their functional role, or add to research on the experiences of online learning librarians as members of expert teams (Wissinger et al., 2018). Such research may provide guidance to academic libraries on defining and supporting evolving areas of librarianship. 


\section{Appendix. Interview Questions}

\section{Professional Variables}

What is your job title?

How long have you been employed as a librarian?

Did you have any other professional librarian jobs before your current position? If yes, what were those job titles?

Where did you obtain your undergraduate degree? What did you major in as an undergraduate student?

Where did you obtain your Master of Library Science degree?

Do you have any other degrees or certifications?

What is the highest degree your institution grants? (Doctoral, Masters, Baccalaureate, etc.)

What is the FTE of your institution? (Or approximate size?)

\section{Online Learning Librarian Roles}

What type of library and department do you work in? (Research, Instruction, Law Library, Medical, etc.)

How is "online learning" defined in your library/department?

Describe your job duties. (Let them talk generally, then ask any necessary follow-ups:) What, if any, are your job duties in instruction? (Online? Face-to-face?)

What, if any, are your job duties in reference? (Online? Face-to-face?)

What, if any, are your department liaison job duties?

What, if any, are your job duties related to creating online instructional materials?

What, if any, are your job duties related to outreach or marketing online library services? 
Which job duty takes up the largest part of your time? (teaching, reference, creating tutorials, etc.)

Are other librarians responsible for any aspect of online learning in your library?

Do you collaborate with other librarians in online learning tools/techniques? Do you train colleagues in online learning tools/techniques?

Are you responsible for assessing the use and effectiveness of online instructional materials at your library? If so, how is this information collected and shared?

Does your institution offer any fully online programs or degrees? If so, what is your relationship to those online programs?

What percentage of your time is spent working with/for distance students and distance faculty?

What do you see as the major trends in online learning librarianship?

In what ways, if any, do you see your role changing in the next five years?

Is there anything else about your role that I didn't ask and you'd like to share?

\section{Online Learning Librarian Skills}

Prior to becoming an online learning librarian, what skills/experiences did you have that helped prepare you for online learning work? Where did you gain these skills? (class in library school, making YouTube videos, etc.)

When you were looking for librarian jobs, what types of jobs were you looking for? Did you expect to become an online learning librarian? What led you to be interested in this work?

When you started your job, did you feel prepared to do the work of an online learning librarian?

If so, what made you feel prepared?

If not, how did you go about gaining skills/becoming more prepared? 
What types of professional development for online learning do you participate in, if any? (Conferences, webinars, reading, etc.)

What types of tools/technologies related to online learning do you work with regularly?

How did you learn to use these tools/technologies?

What types of online instructional materials do you regularly create, if any? (videos, tutorials, etc.) How did you learn to create these types of content?

What tools/technologies do you use to create [videos, tutorials, etc.]?

What information literacy concepts do you cover with online instructional materials?

Has the ACRL Framework influenced the kinds of online instructional materials you create or the content of your instructional materials?

What resources or other institutions do you look to for examples or inspiration for online instructional materials, if any?

Are there any unique skills that you possess that add value to your department/library? How does your online learning work support the teaching and learning of information literacy at your institution?

Is there anything else about your skills that I didn't ask and you'd like to share?

\section{Online Learning Librarian Challenges}

What challenges, if any, do you experience in doing online learning work? (Probe for personal challenges, challenges within your library/organization, professional challenges)

How have you responded to these challenges?

How could your library better support you in overcoming these challenges?

What other challenges, if any, exist for online learning librarians?

How could academic libraries better support online learning librarians in overcoming these challenges? 
How could the profession/professional organizations better support online learning librarians in overcoming these challenges?

Is there anything else related to challenges that you'd like to share?

\section{Demographic Variables (optional)}

What is your age?

How would you define your gender?

How would you define your race or ethnicity? 


\section{References}

Aslanian, C. B., Clinefelter, D. L., \& Magda, A. J. (2019). Online college students 2019: Comprehensive data on demands and preferences. Learning House, https://www.learninghouse.com/knowledge-center/research-reports/ocs2019$\underline{\text { research-report }}$

Association of College and Research Libraries. (October, 2011). Guidelines for instruction programs in academic libraries. www.ala.org/acrl/standards/guidelinesinstruction

Association of College and Research Libraries. (June, 2016). Standards for distance learning library services. www.ala.org/acrl/standards/guidelinesdistancelearning

Association of College and Research Libraries (April, 2017). Roles and strengths of teaching librarians. www.ala.org/acrl/standards/teachinglibrarians

Brandt, J. M., \& Macaluso, S. J. (Summer, 2006). Characteristics and challenges of distance learning librarians: Report to the Distance Learning Section (ED565490). Association of College and Research Libraries, American Libraries Association Distance Learning Section. ERIC. https://files.eric.ed.gov/fulltext/ED565490.pdf

Cassner, M., \& Adams, K. E. (2004). A survey of distance librarian-administors in ARL libraries: An overview of library resources and services. Journal of Library Administration, 41(1-2), 85-96. https://doi.org/10.1300/J111v41n01_08

Day, A., \& Novak, J. (2019). The subject specialist is dead. Long live the subject specialist! Collection Management, 44(2-4), 117-130. https://doi.org/10.1080/01462679.2019.1573708

Frederiksen, L. (2004). Beyond the extended campus library: A brief history of the Distance Learning Section, ACRL. Journal of Library \& Information Services in Distance Learning, 1(1), 45-54. https://doi.org/10.1300/J192v01n01_03 
Frohmann, B. (1994). Discourse analysis as a research method in library and information science. Library and Information Science Research, 16(2), 119-138. https://doi.org/10.1016/0740-8188(94)90004-3

Gandhi, S. (2003). Academic librarians and distance education: Challenges and opportunities. Reference \& User Services Quarterly, 42(2), 138-154.

Ginder, S. A., Kelly-Reid, J. E., \& Mann, F. B. (January, 2019). Enrollment and employees in postsecondary institutions, fall 2017; and financial statistics and academic libraries, fiscal year 2017. National Center for Education Statistics. https://nces.ed.gov/pubsearch/pubsinfo.asp?pubid=2019021REV

Jaguszewski, J., \& Williams, K. (2013). New roles for new times: Transforming liaison roles in research libraries. Association of Research Libraries. www.arl.org/component/content/article/6/2893

Pitts, J. E., Bonella, L., Coleman, J. M., \& Wathen, A. (Eds.) (2019). Library services for online patrons: A manual for facilitating access, learning, and engagement. ABC-CLIO.

Saunders, L. (2018). Information literacy in practice: Content and delivery of library instruction tutorials. The Journal of Academic Librarianship, 44(2), 269-278. https://doi.org/10.1016/j.acalib.2017.12.022

Talja, S. (1999). Analyzing qualitative interview data: The discourse analytic method. Library \& Information Science Research, 21(4), 459-477. https://doi.org/10.1016/S0740-8188(99)00024-9

Tang, Y. (2013). Distance education librarians in the United States: A study of job announcements. The Journal of Academic Librarianship, 39(6), 500-505. https://doi.org/10.1016/j.acalib.2013.08.012

Wissinger, C., Raish, V., Miller, R., \& Borrelli, S. (2018). Expert teams in the academic 
library: Going beyond subject expertise to create scaffolded instruction. Journal of Library Administration, 58(4), 313-333.

https://doi.org/10.1080/01930826.2018.1448648

Yang, S. Q., \& Dalal, H. A. (2015). Delivering virtual reference services on the web:

An investigation into the current practice by academic libraries. The Journal of Academic Librarianship, 41(1), 68-86.

https://doi.org/10.1016/j.acalib.2014.10.003 